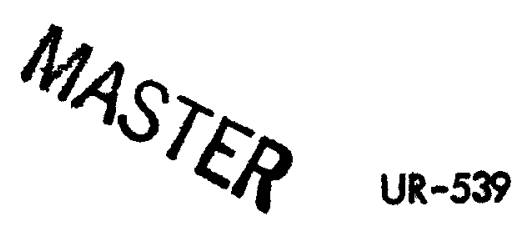

AEC RESEARCH AND DEVELOPMENT REPORT

STUDIES ON LARGE AREA SUB-FABRIC BURNS:

THE EFFECT OF AN AIR SPACE BETWEEN A TWO IAYER SYSTEM

by

Kelly M. Berkley

THE UNIVERSITY OF ROCHESTER ATOMIC ENERGY PROJECT ROCHESTER, NEW YORK 


\section{IIEGGAL MOIIICE}

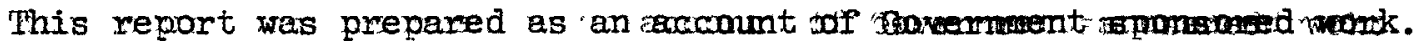

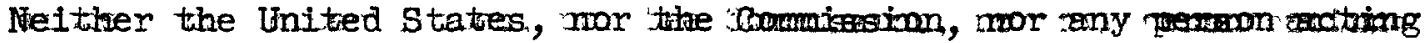
con behallf of the Commisiston:

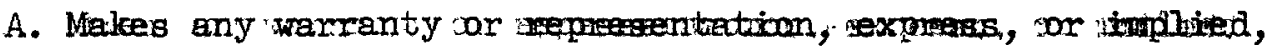

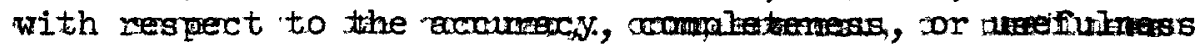

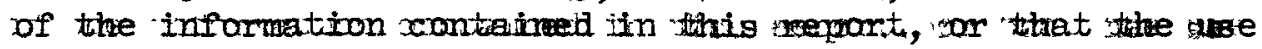

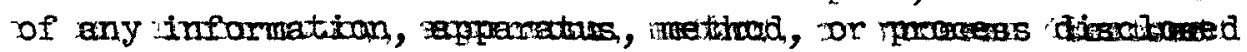

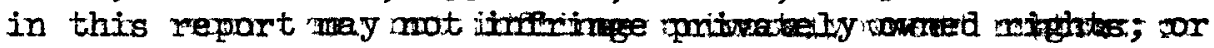

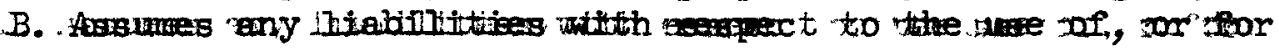

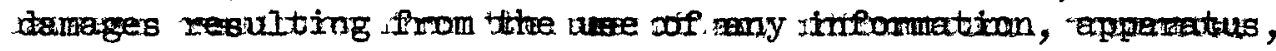
method, or prows distroed in this

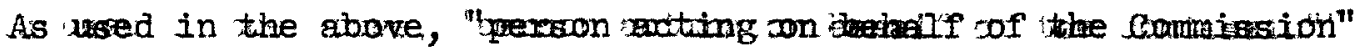

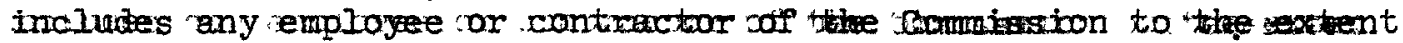

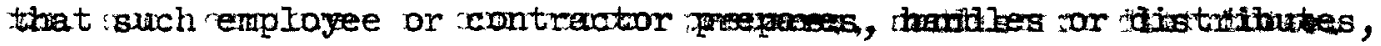

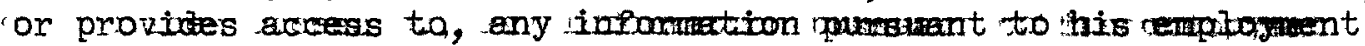
or contract with the comminsion.

Printed in USA. Price 75 cents. Avallable from the Office of Technical Services, Department of Commerce, Washington 25, D. C. 


\section{DISCLAIMER}

This report was prepared as an account of work sponsored by an agency of the United States Government. Neither the United States Government nor any agency Thereof, nor any of their employees, makes any warranty, express or implied, or assumes any legal liability or responsibility for the accuracy, completeness, or usefulness of any information, apparatus, product, or process disclosed, or represents that its use would not infringe privately owned rights. Reference herein to any specific commercial product, process, or service by trade name, trademark, manufacturer, or otherwise does not necessarily constitute or imply its endorsement, recommendation, or favoring by the United States Government or any agency thereof. The views and opinions of authors expressed herein do not necessarily state or reflect those of the United States Government or any agency thereof. 


\section{DISCLAIMER}

Portions of this document may be illegible in electronic image products. Images are produced from the best available original document. 
Biology and Medicine TID-4500, (14th Ed.)

THE UNIVERSITY OF ROCHESTER

Atomic Energy Project

P. 0. Box 287, Station 3

Rochester 20, New York

$$
\text { *** }
$$

Contract W-7401-eng-49 between the U. S. Atomic Energy Commission and the University of Rochester, administered by the Department of Radiation Biology of the School of Medicine and Dentistry.

\title{
STUDIES ON LARGE AREA SUB-FABRIC BURNS:
}

THE EFFECT OF AN AIR SPACE BETWEEN A TWO LAYER SYSTTEM

by

\author{
Kelly M. Berkley
}

Division: Speclal Programs

Section: Flash Burns

Date Completed: $1 / 14 / 59$
Division Head: H. A. Blair

Section Head: J. R. Hinshaw

Date of Issue: $3 / 4 / 59$ 
STUDIES ON IARGE AREA SUB-FABRIC BURNS:

THE EFTECT OF AN AIR SPACE BETWEEN A TWO IAIKR SYSTEM

Kelly M. Berkley

\begin{abstract}
It is well known that protection against radiant energy burns afforded by fabrics may be increased by creating an air space between the fabric and the underlyling skin. Earlier work in this laboratory has also shown that if one layer of fabric is in contact with skin, protection of a two layer fabric system increases progressively as the space between the fabrics changes from two to five millimeters. With the magnesium source, large area sub-fabric burns were produced to determine the effects of stfll greater air spaces between the two layers.

With underwear material in contact with the skin of white pigs, reen poplin material was placed either in contact with or at distances of from one to four centimeters from the underwear. Magnesium flash powder, in 150 gm. charges, was exploded at a distance of $20 \mathrm{~cm}$. from the animals. It was found that combinations of fabric and spacing which resulted in the underwear's remaining intact resulted in the greatest protection. In general, fireretardant treated material was superior to untreated material, and increasing the air space between the two layers decreased severity of the resulting burns.
\end{abstract}


IMTRODUCTION

Observations that clothing will reduce the severity of cutaneous radiant energy burns were first made in Japan (1) following the atomic bomb explosions in Hiroshima and Nagasakl. Subsequently this effect has been studied in the field and in this and other laboratorles $(2,3,4,5,6,7,8,9,10,11)$. The effect is modifled by the fabric's weight, reflectance, and composition $(7,11)$. It is influenced by air spacing and by multiple layers $(2,10)$.

Two thermal sources have been available in this laboratory for these investigations (12, 13): 1) A $24^{*}$ carbon arc searchlight and 2) a magnesium flash powder source. With the first source small area burns can be produceds with the latter, large area burns.

Studies of the influence of an air space between two fabric layers, one of which was in contact with skin, on the production of small area burns showed that as the space between the fabrics increased from two to fire mm. the amount of protection increased (3). This effect deserves further investigation. Since an air space greater than $5 \mathrm{~mm}$. moves the fabric-skin system out of the focal plane of the reflecting mirror of the carbon arc source, these studies were done with the magnesium source.

Since it has also been shown that under certain conditions impregnating the material with a fire-retardant substance may either increase or decrease protection $(3,5)$ afforded by the fabric, fire-retardant treated material was also studied.

\section{METRODS}

\section{Physical8}

150 gms. of magnesium flash powder with an exposure time of 0.7 sec. were exploded $20 \mathrm{~cm}$. from the side of the animal; this provided approximately $20 \mathrm{cal} / \mathrm{cm}^{2}$. The method of firing has been described by Roth et al. (13). 
The skin was exposed through a $3-3 / 4^{m}$ port in a shielded animal container. A movable frame $10^{\infty} \times 10^{\infty}$ supported the outer layer of fabric. The following figure depicts the arrangement used (Figure I).

The fabrics tested were green poplin (Shade 116) weighing $5.40 \mathrm{og}^{\circ} / \mathrm{sq} . \mathrm{yd}, \mathrm{g}$ designated $\mathrm{GRg}$ the same fabric treated with fire-retardant

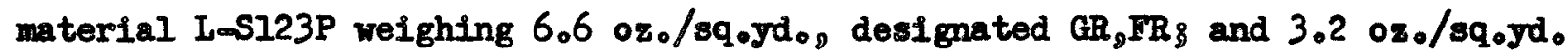
white underwear material. These were supplied by the Quartermaster Research and Engineering Command. The underwear was placed in contact with the skin and was held by the walls of the animal container so that it was snug but not stretched. The poplin fabrics were placed in the novable frame except when they were in contact with the underwear, when they were held in a similar manner as the underwear. Both fabrics were studied in contact with the undarwear and $I_{2}, 2,3$, and $4 \mathrm{~cm}$. from the animal. The cloth was left in place until all burning had ceased.

Statistieal Design

The untreated and treated fabrics were studied in 5 and 3 positions respectively from the animal. In addition, a control burn on bare skin was made. These nine treatments were systematically randomized so that any one might fall on any of 9 positions, on the right side and 4 on the left, of one of the six pigs used.

Lfter the above experiment was done, it was found desirable to study the treated fabric at three and four cm. from the animal. The two treatments of each plus a bare skin burn were randomized so that any one could fall on any site on the side of the anthl. Again there were 5 positions on the right side and 4 on the left. 


\section{MAGNESIUM FLASH}

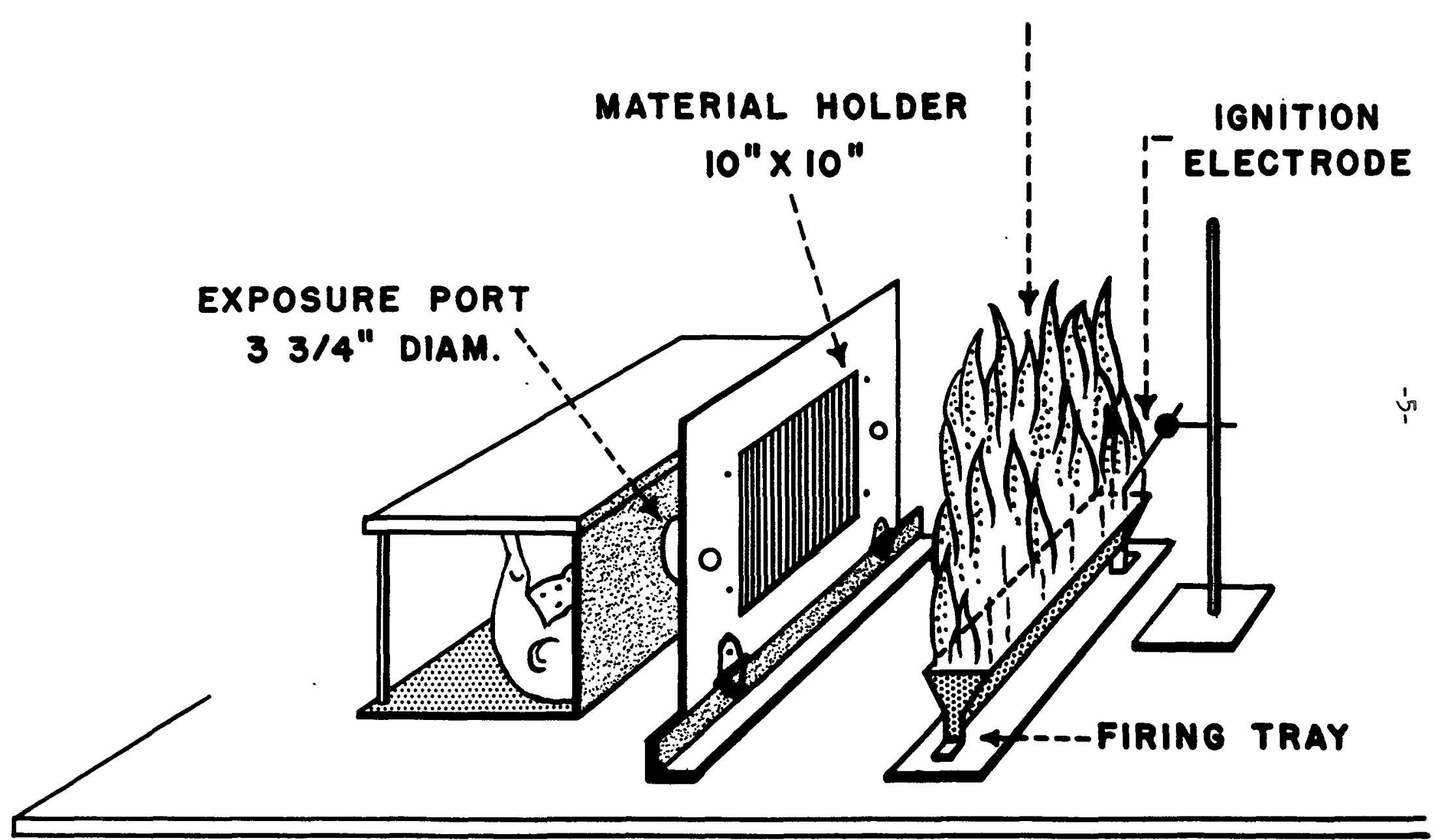

Fig. 1. The experimental method using burning magnesium powder as the thermal source. The $\mathrm{plg}$ is shielded except for a 3-3/4" diameter port. Beneath this the skin is covered snugly by underwear. A movable 10" x 10" frame holds the outer layer of green poplin. The space between underwear and poplin was increased from 0 to $4 \mathrm{~cm}$. by moving this frame. The pig - magnesium tray distance was kept constant at $20 \mathrm{~cm}$. which gives an exposure of $20 \mathrm{cal} / \mathrm{cm}^{2}$. 


\section{Evaluation}

The burns were evaluated 24 hours after their production by the following criteria (14):

$$
\begin{aligned}
& 0 \text { - No burn } \\
& 1+\text { - Erythema } \\
& 2+\text { - Patchy whiteness } \\
& 3+\text { - Uniform whiteness } \\
& \text { 4+ - Steam bleb }
\end{aligned}
$$

The percentage of the exposed area of any grade of burns was estimated in increments of $25 \%$.

The most severe area of the burn was biopsied and fixed in formalin at the time of evaluation of the surface appearance. The sections were stained by the standard hematoxylin and eosin method and by the modified Verhoeff's method of Hinshaw (15)。

Criteria for damage as determined by microscopic examination have been described previously (16). The depth of damage in the dermis was measured with the aid of a micrometer scale in the ocular of the microscope.

\section{Analysis of the Data}

An arbitraxy scoring system described previously was used (4). This system considers only the most severe burns.

\begin{tabular}{ccc}
\hline Grade & Percentage & Score \\
\hline $1+$ & 25 & 1 \\
& 50 & 2 \\
& 75 & 3 \\
$2+$ & 100 & 4 \\
& 25 & 5 \\
& 50 & 6 \\
& 75 & 7 \\
$3+$ & 100 & 8 \\
& 25 & 9 \\
& 50 & 10 \\
& 75 & 11 \\
$4+$ & 100 & 12 \\
\hline
\end{tabular}


A scoring system considering only the depth of damage was used in evaluating the histological sections complete epidermal damage was scored $1 ; 0-0.1 \mathrm{~mm}$. of dermal damage was scored $2 ; 0.1-0.2,3 ; 0.2-0.3,48$ eto.

\section{RISULTS}

\section{Observations of the Behavior of the Fabric}

In both experiments the outer layer of fabric was always destroyed during the exposure. The inner layer of fabric at times showed charring and at other times remained intact. Appendix 4 gives the frequency of this occurrence.

Evaluation

The results of the experimental design are listed together in Appendices 1 and 2. Although from a statistical standpoint, this is not valid, it is felt that the results obtained are independent of the biological behavior of the two sets of animals.

Appendices 1,2,3,4 and 5 and Figures 2 and 3 show the results. At $20 \mathrm{cal} / \mathrm{cm}^{2}$ the untreated fabric cansed a linear decrease in burn severity as the separation increased up to $3 \mathrm{~cm}$. At $4 \mathrm{~cm}$. burn severity rose. At the same time, the frequency with which the underwear charred decreased up to 3 cm. and then sharply increased.

At the same energy level, the treated fabric caused a progressive decrease in burn severity throughout the range of separation studied. The frequency with which the underwear charred decreased also.

\section{DISCUSSION}

The amount of protection afforded by an increasing amount of separation of the outer fabric appears definitely related to the effect of the 
pioune 2

THE EFFECT OF SEPARATION OF OREEN POPLIN FROM SKIN COVERED OY UNDENWEAR MATEAIAL ON SEVERITY OF CUTANEOUS PORCINE DURNS (BUAFACE APPEARANCE) AND FREOUENCY OF GHARRIME OF UNDERwEAR Material PRODUCEO OY $20 \mathrm{cols} / \mathrm{cm}^{2}$. (EXPERIMENT i)

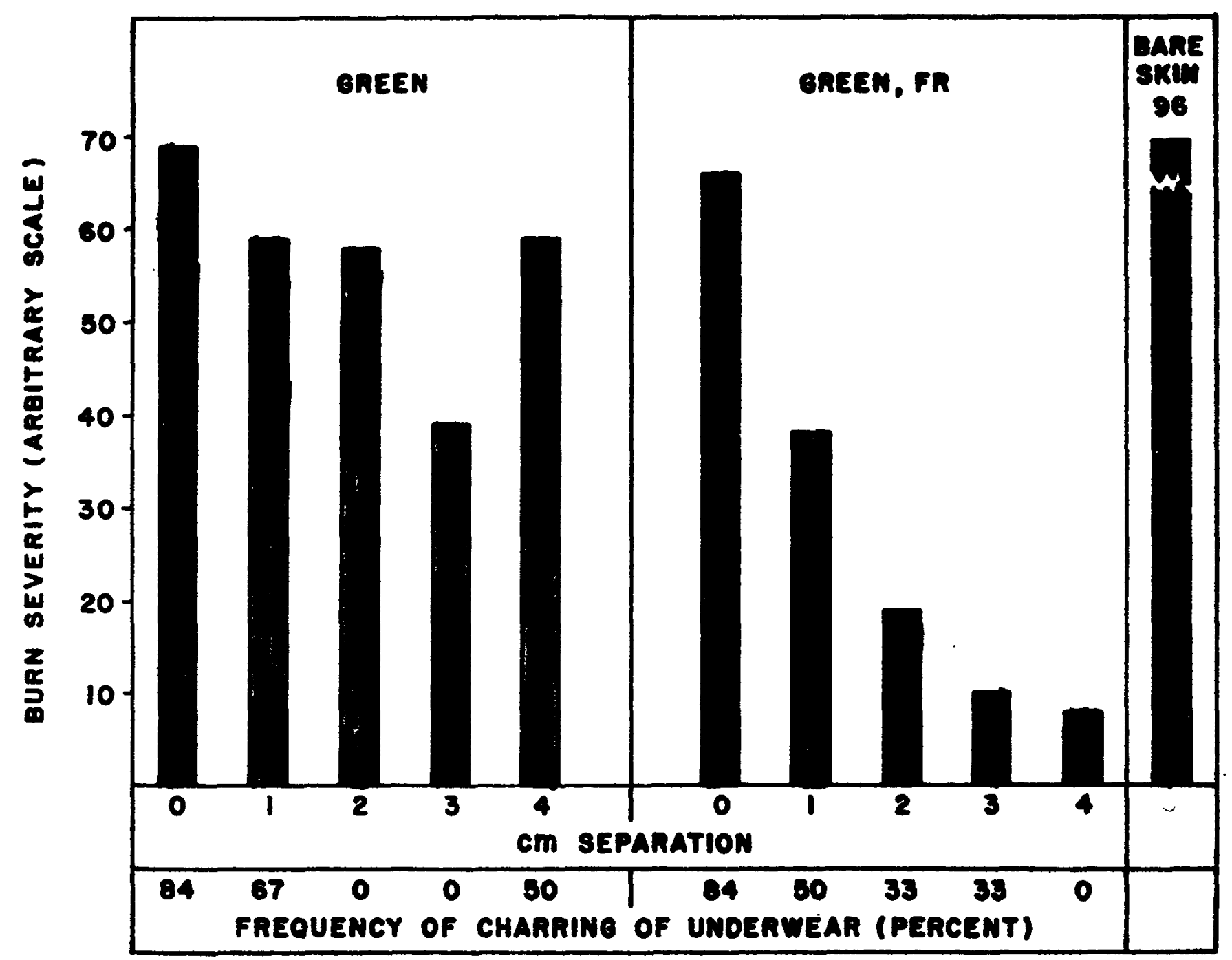


FIGURE 3

THE EFFECT OF SEPARATION OF GREEN POPLIN FROM SKIN COVERED BY UNDERWEAR MATERIAL ON BEVERITY OF CUTANEOUS PORCINE BURNS (DEPTH OF DAMAGE) AND FREOUENCY OF CHARRI OF UNDERWEAR MATERIAL PRODUCED BY $20 \mathrm{cols} / \mathrm{cm}^{2}$. (EXPERIMENT 1)

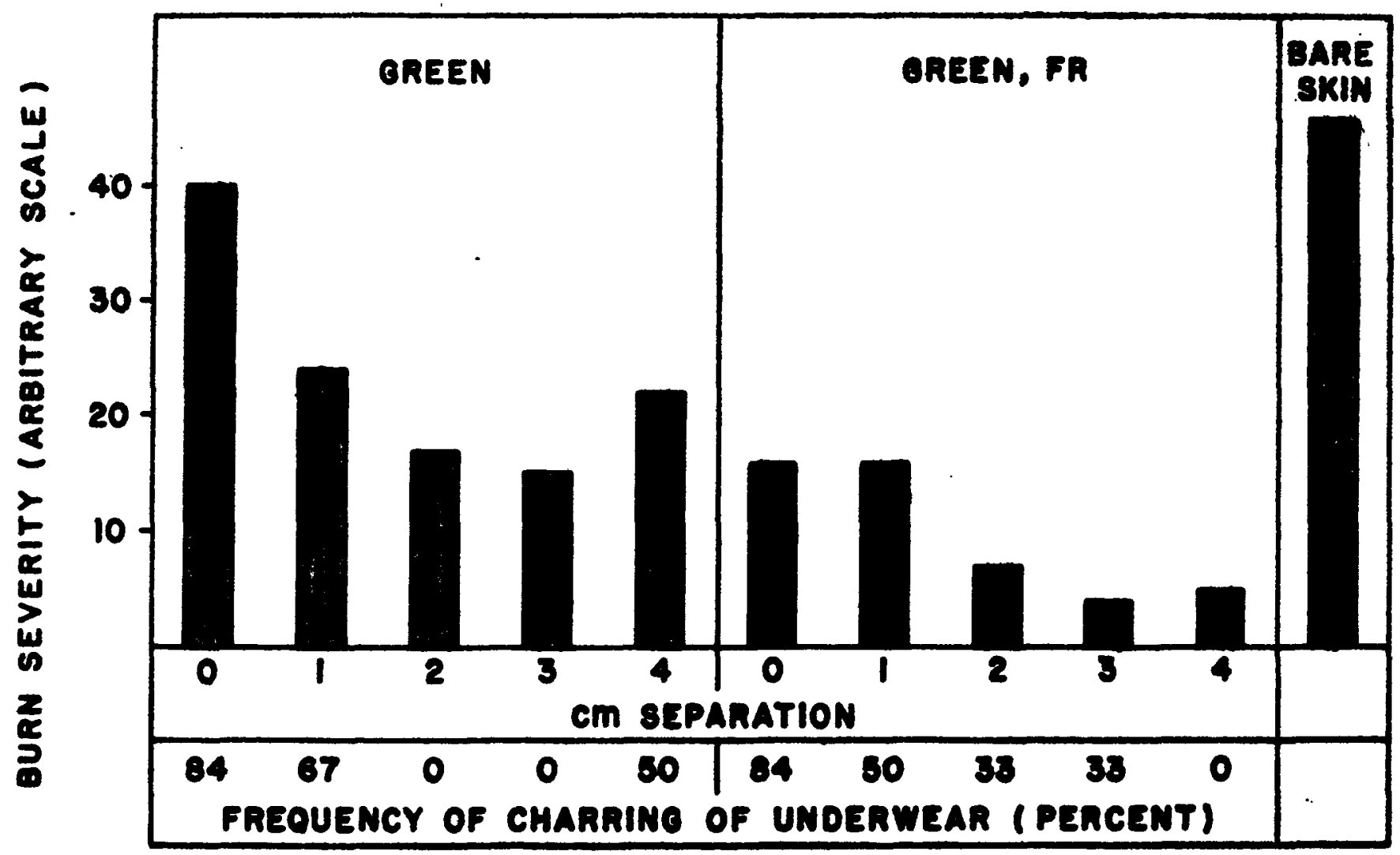


exposure on the underwear material. If the underwear remains intact, burn severity is decreased.

It was expected on the basis of previous investigations (2) that with Increasing separation a reduction of burn severity would be observed. However, at $20 \mathrm{cal} / \mathrm{cm}^{2}$ exposures, less protection was given by the untreated fabric with $4 \mathrm{~cm}$. separation than with $3 \mathrm{~cm}$. separation. This finding covld be explained on the basis of flaming or on the lack of persistence of the outer fabric after the exposure. In these experiments the fabric mas moved toward the source as well as away from the sidn, so that at 4 cm. of separation the cloth $1 \mathrm{~s}$ only $16 \mathrm{~cm}$. from the sources it is, therefore, the recipient of a larger radiant exposure. This wight well result in a shorter persistence time and consequently more serere burn. The abore feature of this experinent is objectionable but cannot be arolded if the magnesium source is used. 


\section{SUMARY AMD COMCLUSIONS}

1. A series of large area sub-fabric burns were produced by exploding 150 gm. of magnesium flash powder at a distance of $20 \mathrm{~cm}$. from the animal. Underwear material was placed in contact with the skin, the green poplin fabric, untreated and treated with a fire retardant substance, was interposed at different distances from the skin. The behavior of the fabric was noted. The burns produced were evalunted by surface appearance and microscopic examination.

2. Hore protection was given by the fire-retardant treated material than by the untreated material.

3. It was observed that with increasing separation burn severity decreased.

4. Two maximum points of protection were found one at $3 \mathrm{~cm}$. separation with untreated fabric and the other at $2 \mathrm{~cm}$. of separation vith the treated fabric. At these points the frequency with which the underwear material remained intact was greatest.

5. The amount of protection is dependent, in a yet unpredictable fashion, upon the type of fabric, the distance of the fabric from the skin, and the amount of energy received by the outer layer of fabric.

6. It is felt that in a two layer system the persistence time of the outer layer of fabric will be a significant factor in the mechanism of protection. 


\section{BIBIIOCANPI}

1. Effects of Atomic Weapons, para. 7.55, Rev。 June 1957, U。 S. Government Printing Office.

2. Barkley, Ko Ho, $_{0}$ The Effect of Lir Space on Sub-Fabric Burns in Swine. Univ. of Rochester, Atomic Energy Project Report, [R-490 (1957)。

3. Berkley, $\mathrm{K}_{0} \mathrm{H}_{{ }_{0}}$ Stodies on Small Area Sub-Fabric Flash Burnso Uniro of Rochestor, Ltomic Fnergy Project Report, UR-493 (1957).

4. Berkley, $K_{0} H_{0}$ and Pearse, $H_{0} K_{0}$, Studies on Iarge Area Sub-Fabric Burns. Univ, of Rochester, Atomic Energy Project Report, UR-494 (1957)。

5. Berkley, K. H., The Relationship Between the Surface Appearance and Depth of Damage of Subfabric and Bare Skin Burns Produced by Radiant Thermal Energy. Univ. of Rochester, Atanie Energy Projeet Report, 'LR-523 (1958).

6. Hixter, G. Jr.. Studies on Flash Burns 8 Further Report on the Protective Qualities of Fabrics as Expressed by a Protective Index. Unir. of Rochester, Atomic Energy Project Report, UR-354 (1954).

7. Mixter, G. JY, Davis, T. P. and Pearse, H. E., The Sab-Fabric Flash Burns Quantitative Effect on Protectivity of Fabric Reflectance, Fabric Weight and Exposure Time. Univ, of Rochester, A tomic Energy Project Report, UR-386 (1955)。

8. Kixter, $G_{0}$ Jro, $_{0}$ and Pearse, H. E., Studies on Flash Burns? The Protection Afforded by 2,4 and 6 Layer Fabric Combinations. Univ. of Rochester. Atomic Energy Project Reporto UR-261 (1953).

9. Porsonal Commanlcation, Naval Materlal Iaboratory, Brooklyn, NoY. 10. Personal Communlestion, Quartermaster Research and Engineering Center, U. S。 Arro, Hatlek, Mass. 
11. Korton, J. H, Kingsley, H, $\mathrm{D}_{\circ,}$ and Pearse, $\mathrm{H}_{0} \mathrm{E}_{\circ}$, Studies on Flash Burns8 Threshold Burns. Surg., Gyn. and Obst. 948317-322 (1952).

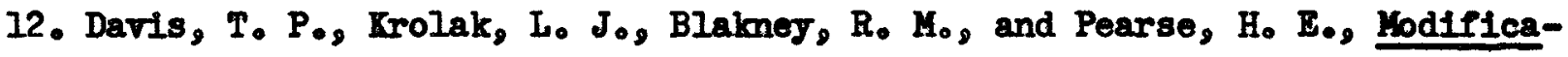
tion of the Carbon Arc Searchlight for Producing Experimental Flash Burns. J.0.S.A. 쓰8 766-769 (1954).

13. Bales, H. W., Both, R. E., Krolak, I. J.g and Pearse, H. E., Braluation of Hagnesium Pouder as a Source for the Production of Large Area Flash Burns on Pig Sirin. Univ. of Rochester, Atomic Bnergy Project Report, UR-436 (1956).

14. Perkins, J. B., Kingsley, H. D., and Pearse, H. E., A Study of Radiant Energy Burns 8 The Effect of Exposure Time and Intensity. Unir. of Rochester, Atomic Energy Project Report, UR-217 (1952).

15. Hinshaw, J. R. and Pearse, H. E., Histologic Techniques for the Difforential Staining of Burned and Normal M1ssues. Surg. Oyn. and Obst. $1038726-730(1956)$.

16. Hinshaw, J. R,, Bales, H. $\mathrm{H}_{0}$, and Pearse, H. $\mathrm{H}_{0}$, The Relationship Between Surface Grade and Depth of Damage of Burns Produced by Radiant Thermal Energy. Univ. of Rochester, Atomic Energy Project Report, UR-440 (1956)。 
Appendix 1

\begin{tabular}{|c|c|c|c|c|c|c|c|}
\hline \multirow{2}{*}{ Fabric } & \multirow{2}{*}{$\begin{array}{l}\text { Space } \\
\mathrm{cm}\end{array}$} & \multicolumn{5}{|c|}{ Grade (Swriface Appearance) } & \multirow{2}{*}{ Seore } \\
\hline & & 0 & $1+$ & 24 & $3+$ & $4+$ & \\
\hline GR & $\begin{array}{l}0 \\
0 \\
0 \\
0 \\
0 \\
0\end{array}$ & & & $\begin{array}{l}25 \% \\
50 \%\end{array}$ & $\begin{array}{r}100 \% \\
75 \% \\
50 \% \\
100 \% \\
100 \% \\
100 \%\end{array}$ & Total & $\begin{array}{l}12 \\
11 \\
10 \\
12 \\
12 \\
12 \\
69 \\
\end{array}$ \\
\hline $\mathbb{G}$ & $\begin{array}{l}1 \\
1 \\
1 \\
1 \\
1 \\
1\end{array}$ & & $\begin{array}{l}25 \% \\
25 \% \\
50 \%\end{array}$ & $\begin{array}{r}100 \% \\
25 \% \\
25 \% \\
75 \%\end{array}$ & $\begin{array}{l}75 \% \\
50 \% \\
75 \% \\
25 \% \\
50 \%\end{array}$ & Total & $\begin{array}{r}8 \\
11 \\
10 \\
11 \\
9 \\
10 \\
59\end{array}$ \\
\hline GR & $\begin{array}{l}2 \\
2 \\
2 \\
2 \\
2 \\
2\end{array}$ & & $\begin{array}{l}25 \% \\
50 \%\end{array}$ & $\begin{array}{l}50 \% \\
75 \% \\
75 \% \\
50 \%\end{array}$ & $\begin{array}{r}100 \% \\
50 \% \\
25 \% \\
50 \% \\
50 \%\end{array}$ & Total & $\begin{array}{r}12 \\
10 \\
7 \\
9 \\
10 \\
10 \\
58 \\
\end{array}$ \\
\hline GR & $\begin{array}{l}3 \\
3 \\
3 \\
3 \\
3 \\
3\end{array}$ & $\begin{array}{l}50 \% \\
75 \% \\
508\end{array}$ & $\begin{array}{l}25 \% \\
25 \% \\
50 \%\end{array}$ & $\begin{array}{r}25 \% \\
25 \% \\
100 \% \\
50 \% \\
50 \%\end{array}$ & $\begin{array}{l}50 \% \\
25 \%\end{array}$ & Total & $\begin{array}{r}5 \\
5 \\
8 \\
10 \\
9 \\
2 \\
39 \\
\end{array}$ \\
\hline 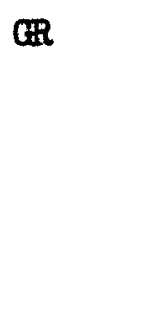 & $\begin{array}{l}4 \\
4 \\
4 \\
4 \\
4 \\
4\end{array}$ & $25 \%$ & $50 \%$ & $\begin{array}{l}25 \% \\
75 \% \\
50 \% \\
25 \%\end{array}$ & $\begin{array}{r}100 \% \\
75 \% \\
100 \% \\
25 \% \\
50 \%\end{array}$ & Total & $\begin{array}{r}12 \\
11 \\
12 \\
9 \\
10 \\
5 \\
59\end{array}$ \\
\hline
\end{tabular}

This table shows the grade and percent of total area burned resulting from exploding 150 gms. of magnesium powder at a distance of $20 \mathrm{~cm}$. from the pig with the green poplin fabric interposed at the specified distance and underwear in contact with the skin. 
Appendix 2

\begin{tabular}{|c|c|c|c|c|c|c|c|}
\hline \multirow{2}{*}{ Fabric } & \multirow{2}{*}{$\begin{array}{c}\text { Space } \\
\text { em }\end{array}$} & \multicolumn{5}{|c|}{ Grade (Surface Appearance) } & \multirow{2}{*}{ Score } \\
\hline & & 0 & 18 & 24 & $3+$ & $4+$ & \\
\hline $\mathrm{GR}_{0}, \mathrm{FR}$ & $\begin{array}{l}0 \\
0 \\
0 \\
0 \\
0 \\
0\end{array}$ & & 258 & $\begin{array}{l}25 \% \\
100 \%\end{array}$ & $\begin{array}{r}100 \% \\
75 \% \\
75 \% \\
100 \% \\
100 \%\end{array}$ & Total & $\begin{array}{r}12 \\
11 \\
11 \\
12 \\
12 \\
8 \\
66\end{array}$ \\
\hline $\mathrm{CAR}_{0} \mathrm{FR}$ & $\begin{array}{l}1 \\
1 \\
1 \\
1 \\
1 \\
1\end{array}$ & $\begin{array}{r}25 \% \\
100 \% \\
25 \%\end{array}$ & $\begin{array}{l}75 \% \\
25 \% \\
25 \%\end{array}$ & $\begin{array}{r}508 \\
1008 \\
758\end{array}$ & $\begin{array}{l}25 \% \\
75 \%\end{array}$ & Total & $\begin{array}{r}3 \\
0 \\
9 \\
17 \\
8 \\
7\end{array}$ \\
\hline $\mathrm{GR}_{\mathrm{D}} \mathrm{FR}$ & $\begin{array}{l}2 \\
2 \\
2 \\
2 \\
2 \\
2\end{array}$ & $\begin{array}{r}100 \% \\
100 \% \\
50 \% \\
50 \% \\
25 \% \\
50 \%\end{array}$ & $\begin{array}{l}50 \% \\
25 \% \\
25 \%\end{array}$ & $\begin{array}{l}25 \% \\
75 \% \\
25 \%\end{array}$ & & Total & $\begin{array}{r}0 \\
0 \\
2 \\
5 \\
7 \\
5 \\
19\end{array}$ \\
\hline $\mathrm{CR}_{9}, \mathrm{FR}$ & $\begin{array}{l}3 \\
3 \\
3 \\
3 \\
3 \\
3\end{array}$ & $\begin{array}{r}100 \% \\
50 \% \\
50 \% \\
100 \% \\
100 \% \\
100 \%\end{array}$ & $\begin{array}{l}25 \% \\
25 \%\end{array}$ & $\begin{array}{l}258 \\
258\end{array}$ & & Total & $\begin{array}{r}0 \\
5 \\
5 \\
0 \\
0 \\
0 \\
10 \\
\end{array}$ \\
\hline $\mathrm{CR}_{9} \mathrm{PR}$ & $\begin{array}{l}4 \\
4 \\
4 \\
4 \\
4 \\
4\end{array}$ & $\begin{array}{r}100 \% \\
100 \% \\
100 \% \\
50 \% \\
50 \% \\
100 \%\end{array}$ & $50 \%$ & $50 \%$ & & Total & $\begin{array}{l}0 \\
0 \\
0 \\
6 \\
2 \\
0 \\
8\end{array}$ \\
\hline
\end{tabular}

This table show the grade and pereent of total area burned resulting from exploding 150 of of onesin powder at a distance of $20 \mathrm{~cm}$. from the pig with the firessetardant treated green poplin fabric interposed at the opecifled distance and inderwear in contact vith the skin. 


\section{Appendix 3}

\begin{tabular}{|l|c|c|c|c|c|}
\hline \multirow{2}{*}{ Fabric } & \multicolumn{5}{|c|}{ Space (cm) } \\
\cline { 2 - 6 } & 0 & 1 & 2 & 3 & 4 \\
\hline $\mathrm{GR}, \mathrm{FR}$ & 69 & 59 & 58 & 39 & 59 \\
\hline BARE SKTN & 66 & 38 & 19 & 10 & 8 \\
\hline
\end{tabular}

This table shows the total score for the burns produced by the magnesium source at a distance of $20 \mathrm{~cm}$. under the specified conditions and graded by surface appearance. 
Appendix 4

\begin{tabular}{|l|c|c|c|}
\hline \multirow{2}{*}{ Fabric } & \multirow{2}{*}{ Space (on) } & Underwear \\
\cline { 2 - 4 } & \% Char & \% Intact \\
\hline \multirow{2}{*}{ CR } & 0 & 84 & 16 \\
& 1 & 67 & 33 \\
& 2 & 0 & 100 \\
& 3 & 0 & 100 \\
CR, FR & 4 & 50 & 50 \\
& 0 & 84 & 16 \\
& 1 & 50 & 50 \\
& 2 & 33 & 67 \\
& 3 & 33 & 67 \\
& 4 & 0 & 100 \\
\hline
\end{tabular}

This table shows the behavior of the underwear material under the specified conditions produced with the magnesium source at $20 \mathrm{~cm}$. distance. 


\section{Appendix 5}

\begin{tabular}{|c|c|c|c|c|c|c|c|c|c|c|c|}
\hline \multirow{3}{*}{ Fabric } & \multirow{3}{*}{$\begin{array}{l}\text { Space } \\
\text { on. }\end{array}$} & \multirow{3}{*}{$\begin{array}{c}\text { Ho } \\
\text { Buren }\end{array}$} & \multicolumn{8}{|c|}{ Depth of Damage } & \multirow{3}{*}{ Seore } \\
\hline & & & \multirow{2}{*}{$\begin{array}{l}\text { Complete } \\
\text { Bpidernal }\end{array}$} & \multicolumn{7}{|c|}{ Dermal ( $\left.\mathbf{m}_{0}\right)$} & \\
\hline & & & & $0-0.1$ & $0.1-0.2$ & $0.2-0.3$ & $0.3-0.4$ & $0.4-0.5$ & $0.5-0.6$ & $0.6-0.7$ & \\
\hline $\mathbf{G}$ & $\begin{array}{l}0 \\
1 \\
2 \\
3 \\
4\end{array}$ & & $\begin{array}{l}1 \\
1 \\
1\end{array}$ & $\begin{array}{l}2 \\
1\end{array}$ & $\begin{array}{l}1 \\
2 \\
4 \\
2 \\
4\end{array}$ & $\begin{array}{l}4 \\
1 \\
1 \\
1\end{array}$ & $\begin{array}{l}1 \\
1\end{array}$ & & & $\begin{array}{l}1 \\
1\end{array}$ & $\begin{array}{l}40 \\
24 \\
17 \\
15 \\
22\end{array}$ \\
\hline CAR, $\sqrt{R R}$ & $\begin{array}{l}0 \\
1 \\
2 \\
3 \\
4\end{array}$ & $\begin{array}{l}1 \\
3 \\
4 \\
3\end{array}$ & $\begin{array}{l}1 \\
1 \\
1 \\
1\end{array}$ & $\begin{array}{l}1 \\
2 \\
2\end{array}$ & $\begin{array}{l}3 \\
2 \\
2\end{array}$ & 2 & 1 & & & & $\begin{array}{c}16 \\
16 \\
7 \\
4 \\
5\end{array}$ \\
\hline Bare Shdn & & & & & & & & & 2 & 4 & 46 \\
\hline
\end{tabular}

This table abows the result of microseopic examination of the burns produced by the menesion sovrce at a distance of $20 \mathrm{~cm}$. Pron the antmal with one lajer of fabric interposed at the specified distance, the other layer of underwear in contact with the sidin. 